\title{
Federal-State Relations and Tourism Public Policy, New South Wales, Australia
}

\author{
Dianne Dredge
}

School of Environmental Planning, Griffith University, Nathan, Queensland 4111, Australia

\section{John Jenkins}

School of Social Sciences, The University of Newcastle, Callaghan, New South Wales 2308, Australia

In Australia, it has become academic dogma that federalism is a problem rather than an asset. Nevertheless, federalism has significant advantages and is likely to remain an important model for systems of government worldwide. In the case of tourism, overlapping jurisdictions, multiple accountabilities and countervailing power are generally seen to impede effective tourism policy development. This paper goes beyond criticisms of federalism, to investigate the dynamics of federal-State relations in an effort to understand how cooperation in the tourism policy arena can be improved. Using a case study of New South Wales, this paper examines the effects of government personalities, political cycles, shifts in organisational structures and divergent interpretations of globalisation on governments' interest in cooperation.

Keywords: Intergovernmental relations, federalism, tourism public policy, coordination, tourism organisation, New South Wales, Australia

\section{Introduction}

Federalism, like a maze of mad mirrors, distorts, enlarges, diminishes, confuses, frustrates and stimulates all at once (Painter, 1988: 65).

Over the last two decades, there has been accelerated change in systems of governance worldwide (e.g. Galligan, 1995; Painter, 1998a; Watts, 1999). Global economic restructuring, an attachment to neo-liberal economic philosophies and massive social changes have contributed to the transformation of public administration structures and practices in many countries (e.g. Fagan \& Webber, 1994; Hede \& Prasser, 1993; Painter, 1998a). There have been interrelated efforts to make bureaucracy smaller, to move from administration to managerialism, and to increase the efficiency and effectiveness of policy processes and programmes (Painter, 1998a). There has also been a strong push to devolve government responsibilities (e.g. to other levels of government; corporatisation; privatisation or shedding of assets), and a corresponding emphasis on the role of local government as an important and legitimate unit of government.

These trends have placed increasing pressure on all units of government to forge more effective, cooperative relations at both international and domestic levels. At an international level, there has been pressure for governments to 'pool their sovereignties' to gain strategic social, economic and technological benefits (Watts, 1999: 4; see also Henderson, 2001). This trend has led to the formation of, 
for example, supranational organisations such as the European Union, and trade alliances, such as the North American Free Trade Agreement (NAFTA) and the Closer Economic Relations (CER) Treaty between Australia and New Zealand. At a domestic level, pressure has been focused on improving cooperation (1) between agencies within the same unit of government (i.e. intra-governmental relations); and (2) between different levels of government within federal systems (Chapman, 1997; Wanna et al., 1992). In federal systems of government the challenges of greater cooperation and clarification of articulations between policy making in different sectors and by different units of government are, arguably, the most vexed.

While there is no single model of federalism, federal systems of government are typically characterised by a tiered government structure, where powers and responsibilities are divided between different units of government, and where no unit is subordinate to any other. Watts (1999:6) observes that federal systems are:

based on the presumed value and validity of combining unity and diversity and of accommodating, preserving and promoting distinct identities within a larger political union. The essence of federalism as a normative principle is the perpetuation of both union and non-centralisation at the same time.

Overlapping jurisdictions, administrative complexity and duplication of effort are among familiar and sustained criticisms of federalism, frequently identified as impediments to effective and efficient policy making (e.g. Chapman \& Wood, 1984; Wanna et al., 1992; Wiltshire, 1986). Nonetheless, at least in Australia, the wholesale reworking of the federal system seems unlikely. In a comparison of federal systems, Watts (1999) claims that in spite of its critics, the Australian federal system (constituted in 1901) has displayed both flexibility and adaptability, making it the fourth oldest federation in the world after the United States (1787), Switzerland (1848) and Canada (1867). Values and ideas, entrenched over time as Australia was transformed from a penal colony to a modern nation state, have contributed to the development of distinct state and federal personalities (e.g. Wiltshire, 1986), which have reinforced the bi-communal status quo of Australia's federalism.

'Cooperative federalism' has emerged as an operational ideal and has been gaining currency in political rhetoric at both levels of government (Painter, 1996). The term refers to the acceptance of federal-state sovereignties embedded in the constitutional division of powers, and embodies continuing interdependent autonomy with agreed joint benefits (Painter, 1996). However, turning the ideal of cooperative federalism into operational reality requires greater understandings of the characteristics and dynamics of intergovernmental relations (e.g. Galligan et al., 1991; Painter, 1998b).

The aim of this paper is to critically examine intergovernmental relations in the tourism public policy domain and to assess opportunities for and impediments to cooperation between Commonwealth and New South Wales (NSW) State Governments. The focus is principally upon State-federal relations in the period 1945-2000, though some reference is necessarily made to influential developments in local government and other States. Relations between agencies within the same unit of government (i.e. intragovernmental relations) are not a concern of this paper. A second, less explicit aim is to add balance to discussions 
of intergovernmental relations in tourism literature, which have tended to emphasise the disadvantages of federalism for tourism policy making. It has become academic dogma that federalism is a 'problem' rather than an asset, that we should seek clearly defined tourism-related roles for each level of government, and that these goals are critical to the development of sustainable tourism policies. What many tourism analysts fail to consider is that at any point in time, a particular level of government may be predisposed (ideologically) and / or better resourced to undertake particular activities, or that the flux of interest and different policy approaches adopted by different levels of government may offer a level of responsiveness and flexibility that may not be forthcoming under a rigid, coordinated framework of intergovernmental relations.

This Australian-based study of intergovernmental relations can be placed within the broader body of literature on interorganisational relations (IOR), where there is a rapidly expanding body of knowledge dealing with tourism. For example, business-government relations (e.g. Jenkins, 2001); structures of and relations between tourism organisations (e.g. Pearce, 1996a, 1996b, 1996c; Selin \& Beason, 1991) or between tourism and other government organisations (Lovelock, 2001); and partnerships and collaboration generally (e.g. Bramwell \& Lane, 2000; Bramwell \& Sharman, 1999; Hall, 1999). Interorganisational relations can stem from common, mutually beneficial goals, or where cooperation will yield satisfactory access to resources or favourable policy outcomes to both parties. Interorganisational relationships may be short to long term, developed according to mutual need, and may be based on financial, technical or human resource needs, and include customer or client referrals (Hall \& Jenkins, 1995; Pearce, 1992; Selin \& Beason, 1991). According to Pearce (1992), two main approaches to studying this interaction have emerged. The first is one based on exchange theory as presented in the seminal paper by Levine and White (1961, in Pearce, 1992), where organisations are seen to interact voluntarily (perhaps forming policy coalitions) to achieve mutual organisational goals. The second approach stresses power or resource dependency (Pearce, 1992; Pfeffer \& Salancik, 1978, in Selin \& Beason, 1991) and treats the interorganisational network as a political economy where organisations are induced to interact by a more powerful organisation (or collection of organisations) (Hall \& Jenkins, 1995). This paper adopts an alternative approach, influenced by recent ontological debates about the nature of understanding and the increasing rejection of universal models and overarching theories (e.g. Hollinger, 1994). The paper rejects the notion that there is one single lens or framework of understanding that can explain intergovernmental relations. Instead, 'thick' description, drawing upon exchange and resource dependency theories as well as broader theories of social, political and economic change, is used to describe and explain NSW State and federal relations with respect to the tourism policy arena. This approach provides rich explanations of policy making and understandings of the different government personalities involved.

In addressing the above mentioned aims, this paper is divided into three main sections. First, the paper examines, in broad theoretical terms, the nature and characteristics of federalism and its implications for intergovernmental relations in the tourism policy arena. Particular attention is focused on the challenges of cooperative tourism public policy making. Secondly, the case study is presented, 
providing a critical analysis of the historical context and evolution of NSW State-federal relations in the tourism policy arena. The investigation of federal-State relations is based on the analysis and comparison of a wide variety of sources, including parliamentary debates, secondary statistical sources, annual reports, policy documents and personal communications. Thirdly, the paper reflects upon the findings in a discussion of the challenges in achieving cooperative tourism policy making.

\section{Federalism and Intergovernmental Relations}

Federalism is not a modern system of political organisation. Aggregate communal structures aimed at fostering trade and securing defence were used by the ancient Israelites and by Native Americans more than 3200 years ago (Watts, 1999). Yet it is the United States constitution, adopted in 1797, that is widely regarded to be the first modern federal system of government, and an extremely influential model in the proliferation of federal systems over the last 100 years (Wiltshire, 1986). To 1999, there were 23 systems of government of a federal character, encompassing $40 \%$ of the world's population (Watts, 1999). Moreover, the relevance and appeal of federal systems as a form of political organisation continue to grow as a result of global and local pressures. That is, there is growing pressure to form more strategic and competitive economic and social units and, simultaneously, there is an increasing emphasis on protecting and maintaining regional distinctiveness and control at the local level. Federal systems provide a vehicle for shared rule through common institutions to achieve a 'higher' national common good, and regional self-rule to protect local interests and values (e.g. Riker, 1964; Watts, 1999).

There are a number of generally agreed characteristics of federal systems:

- at least two orders of representative government;

- a formal division of legislative and executive authority and an allocation of revenue resources so that autonomy of the units is genuine;

- provision for the representation of the regional or sub-national views within the federal policy making institutions, usually as a second chamber (e.g. Senate);

- a supreme written constitution not unilaterally amendable;

- an umpire, in the form of courts or provisions for a referendum, when disputes between units cannot be resolved; and

- institutions and processes facilitating intergovernmental collaboration (e.g. Watts, 1999; Wiltshire, 1986).

Nonetheless, federal systems can vary significantly in many ways, including: the number of constituent units of government; the level of cooperation and collaborative policy making practices across units; the division of powers and responsibilities; the allocation of revenue-raising powers; the methods of constitutional change; and the characteristics of financial interdependency. The social and economic characteristics of constituent units, which give rise to and perpetuate regional distinctiveness, play a major role in the nature of intergovernmental relations.

In Australia, the different origins and philosophical underpinnings of the colonial administrations meant that they were highly competitive, and that each 
had different ideas about the nature of the proposed federation, the relationships between the States and the proposed Federal Government, and the division of responsibilities (Balmer, 1989; Painter, 1988). The push for the creation of a federal system of government was based on the notion that, as growing colonies with increasing international trade and involvement in world affairs, each administration could benefit from a unified approach. Agreement was reached to create a dual system of sovereignty whereby the States came together to create a Commonwealth Government that was vested with a limited number of specified 'exclusive' powers relating to issues of international, national and interstate significance that were best dealt with on a collective basis. The States and the Commonwealth shared responsibility for some 'concurrent' powers such as collection of income taxes and other revenue collection, and all powers not specifically mentioned became 'residual' powers, the responsibility for which fell to the States (Fenna, 1998). In essence, it was a union of political units without real unity, where existing political traditions and centralised State political and administrative structures could continue (Dicey, 1915, in Reid, 1974; Wiltshire, 1986). The States envisaged a form of coordinate federalism, where they would retain substantial autonomy over a wide variety of powers and would seek to coordinate policy making with the Commonwealth in areas of concurrent responsibility (e.g. Holmes \& Sharman, 1977).

However, changes to federal-State fiscal relations over the course of the 20th century increased the Commonwealth's financial strength, and had a considerable impact upon the power and resources that the States could harness. World War I, and then the Great Depression of the 1920s and 1930s, created conditions ripe for the Commonwealth Government to exercise more intrusive national economic leadership. At the time, the States were borrowing heavily to fund a range of programmes aimed at modernising infrastructure, addressing high unemployment, and improving competitiveness. Concerned at the level of State borrowings, the Commonwealth established a Loan Council in 1928 to coordinate the States' undertakings. The States' decision in 1942 to cede to the Commonwealth the sole rights to set levels and collect personal income taxes, consolidated the Commonwealth's economic leadership shift. While the agreement was originally intended as a temporary measure to redress the financial costs associated with World War II, a favourable High Court decision in the post-war period meant that the States did not immediately regain the right to collect personal income taxes. The States' incomes were severely restricted by this decision. As a result, the Commonwealth established a system of State compensation in the form of large untied grants. Further contributing to the dominance was the Commonwealth's sole right to levy excise, sales and other forms of consumer tax. This situation has led to an acute vertical fiscal imbalance unlike other federal systems, such as those of Canada and the US, countries from which Australia engages in policy diffusion. In brief, the Commonwealth Government collected $77 \%$ of taxation revenue in $1999-2000$ and spent $53 \%$. The States and Territories accounted for $19 \%$ of revenue and $42 \%$ of expenditure. Local government collected just $4 \%$ of taxation revenue and spent $5 \%$ (Australian Bureau of Statistics (ABS), 2000; Marshall, 1997). The fiscal imbalance that characterises Australian federalism, and strengthens the Commonwealth's position 
in relation to the States, no doubt plays an important role in how values, ideas and interests brought to overlapping policy processes are mediated.

Concurrent and shared powers have been the sources of most federal-State conflicts over the course of the 20th century (e.g. see Mercer, 2000). Globalising trade, increasing social and political involvement in world affairs, and expanding international responsibilities (e.g. with respect to the economy and the environment), have prompted the Commonwealth Government to express an interest, and a responsibility in some cases, in an expanding array of policy sectors. Judicial interpretations of the national interest have tended to reinforce this expansion of Commonwealth interests in many areas of policy making, giving rise to an increasingly tangled set of relations (e.g. Aitkin \& Jinks, 1980; Fenna, 1998; Parkin, 1996; Wanna et al., 1992). Overlapping policy responsibilities opens up opportunities for the policy of one government to intentionally or unintentionally influence the agendas, decisions, actions and processes of other governments.

In most federal systems, intergovernmental relations embrace complex networks of relations and administrative structures between ministers, bureaucrats, parliaments and the courts. Parliaments are involved only to a limited extent in the day-to-day dynamics (Saunders, 1986). The structural framework provided by the constitution, or by specific legislation, provides the scaffolding for the day-to-day practices and routines of interaction, and was traditionally the focus of academic attention. Typologies of intergovernmental relations have also emerged from this focus on structure, such as Mathews' (1974) identification of concurrent, overlapping, separate or coordinate relations. Describing structural matters, however, is notably easier than explaining the processes within and around a structure.

The above mentioned criticisms of federalism are being balanced by interest in developing cooperative federalism. According to Painter (1996: 91-2):

The very things for which it [Australian federalism] is often condemned that it creates overlapping and confusing systems of responsibility and accountability, for example - are those for which it might be applauded. Multiple accountability, even if 'messy', affords more, not less, access and responsiveness. The separate 'happiness schemes' of state and commonwealth governments may sometimes be frustrated in the search for compromise and consensus, tempering elective autocracy with flexibility and responsiveness, but they are never denied all of their ambitions.

The disproportionate financial control embedded in fiscal arrangements influences the achievability of cooperative federalism. In other words, Commonwealth financial strength makes cooperation of the States a matter of necessity, while the Commonwealth's more limited power over domestic issues means that cooperation is essential for the implementation of many federal policies and programmes (Aitkin \& Jinks, 1980).

The ideal of cooperative federalism, however, requires a more balanced understanding of relationships between the dynamics of intergovernmental relations and their structures. In this context, there has been growing recognition that characteristics of interaction are also underpinned by the ideas, beliefs and values that constituent governments bring to their relations with other units, and 
to the structures that frame intergovernmental relations. This interplay of different bureaucratic cultures and the ideologies of constituent governments occurs on both formal and informal levels. However, developing understandings of this interplay is difficult given the frequently obscure nature of dialogues embedded within day-to-day practices and routines.

Formal intergovernmental agreements and cooperative structures have frequently been used as a tool in increasing cooperation, reducing duplication of effort and in easing State-federal antagonisms (Galligan et al., 1991; Wanna et al., 1992). Recent studies suggest that formal intergovernmental agreements, underpinned by an agreed division of responsibilities, do not necessarily reduce the problem of fragmented, unilateral policy making (e.g. Chapman, 1997). Shared responsibilities and overlapping jurisdictions are not always counterproductive and do not always lead to inefficient or ineffective policy outcomes (Painter, 1998b). On this basis, there has been increased emphasis on developing a type of flexible and dynamic cooperative federalism that combines continuing interdependent autonomy with agreed joint benefits (Painter, 1996). However, developing cooperative federalism with reference to tourism or any other policy arena requires sound understandings of the institutions of the Australian state. Specifically, better understandings of the complex interrelations between the formal and informal structures of governments, and of the personalities involved in tourism policy making, are needed. This kind of recognition has stimulated the re-emergence of research that focuses on the effects of intergovernmental relations in several policy sectors (e.g. Galligan et al., 1991; Painter, 1996, 1998b).

In the tourism policy arena, cooperation between different levels of government is also evidenced in many countries (Dredge, 2001; Hall, 1998; Hall et al., 1997; Jenkins, 1995; Lovelock, 2001). Much of this work has centred on the formal structures and linkages between national and sub-national units of government and the flows of policy making between formal tourism organisations (e.g. Elliot, 1997; Jefferies, 2001; Pearce, 1992, 1996a, 1996b, 1996c). In Australia, much of the literature examining federalism and tourism policy focuses largely on complex and overlapping divisions of responsibilities (e.g. Hall, 1998; Mercer, 2000). However, critical issues relating to the dynamics of intergovernmental relations (as opposed to structures), and the impact of federalism and intergovernmental relations on tourism policy making have been relatively neglected.

In an overview of the effects of federalism on policy making, Painter (1988) argues that positive and negative effects can be organised around three main themes: countervailing power, overlapping jurisdictions and multiple accountabilities. Based on Painter's work, Table 1 summarises the effects that federalism can have on policy making. The following examination of intergovernmental relations in the tourism policy arena explores these themes, and their positive and negative impacts.

Tourism is a relatively new area of policy making. It was not a particularly important social or economic phenomenon in the 19th century, and was not specifically mentioned in the Australian Constitution (e.g. Hall, 1998). Put simply, tourism became a residual power, falling within the States' area of responsibility. However, as tourism has expanded, it has become a very power- 
Table 1 Effects of federalism on policy making

\begin{tabular}{|c|c|c|c|}
\hline & $\begin{array}{l}\text { Countervailing } \\
\text { power }\end{array}$ & $\begin{array}{l}\text { Overlapping } \\
\text { jurisdictions }\end{array}$ & $\begin{array}{l}\text { Multiple } \\
\text { accountabilities }\end{array}$ \\
\hline $\begin{array}{l}\text { Potential } \\
\text { positive } \\
\text { impacts }\end{array}$ & $\begin{array}{l}\text { Permits the States to } \\
\text { project their interests } \\
\text { and values. } \\
\text { Enhances pluralist } \\
\text { input into policy } \\
\text { making. } \\
\text { Enhances policy } \\
\text { debate. } \\
\text { Smaller government } \\
\text { can impart in-depth } \\
\text { local knowledge to } \\
\text { higher order } \\
\text { governments. }\end{array}$ & $\begin{array}{l}\text { Increased opportunity } \\
\text { to put issues on the } \\
\text { agenda. } \\
\text { Stimulates policy } \\
\text { diffusion across the } \\
\text { States. } \\
\text { Increases economies of } \\
\text { scale (e.g. in } \\
\text { marketing and } \\
\text { regional development) } \\
\text { through cooperation. } \\
\text { Increases likelihood of } \\
\text { accountability. }\end{array}$ & $\begin{array}{l}\text { Multiple points of } \\
\text { access into the policy } \\
\text { making process. } \\
\text { Increased competition } \\
\text { across units of } \\
\text { government. } \\
\text { Increased propensity } \\
\text { to generate } \\
\text { knowledge, for policy } \\
\text { change and for } \\
\text { innovation. }\end{array}$ \\
\hline $\begin{array}{l}\text { Potential } \\
\text { negative } \\
\text { impacts }\end{array}$ & $\begin{array}{l}\text { Majority frustration. } \\
\text { Political point scoring. }\end{array}$ & $\begin{array}{l}\text { Duplication of effort. } \\
\text { Resource waste. } \\
\text { Administrative } \\
\text { complexity. } \\
\text { Uncertainty. } \\
\text { Policy incompatibility. }\end{array}$ & $\begin{array}{l}\text { 'Buck-passing'. } \\
\text { Dispersed authority } \\
\text { leads to lack of clarity } \\
\text { of powers. } \\
\text { Lack of leadership } \\
\text { initiative. }\end{array}$ \\
\hline
\end{tabular}

Adapted from Painter, 1988

ful social, economic and cultural force. It has also become an important tool in regional development, and its importance and volatility have been amply illustrated in the tourism literature. Figure 1 shows significant policy events over the period 1945 to 2000 and should be read in conjunction with the following explanation of events.

\section{Federal-NSW Intergovernmental Relations and Tourism Policy}

\section{5-1959}

Direct and indirect public sector involvement in tourism policy making in Australia can be traced to the 19th and early 20th centuries (e.g. Dredge, 2001; Hall, 1998; Jenkins, 2001; Leiper, 1980; Richardson, 1999). Prior to 1945, governments across Australia were generally more preoccupied with providing basic infrastructure to service the growing economy and in addressing the social and economic impacts of the two World Wars rather than fostering tourism. However, the end of World War II brought a new period of national growth and an expansion in the Federal Government's range of concerns (Halligan \& Power, 1992). Returning soldiers looking for employment, the influx of immigrants from Europe looking for a new life and the need to refocus an economy that had been almost exclusively geared towards the war effort, stimulated both Federal and 


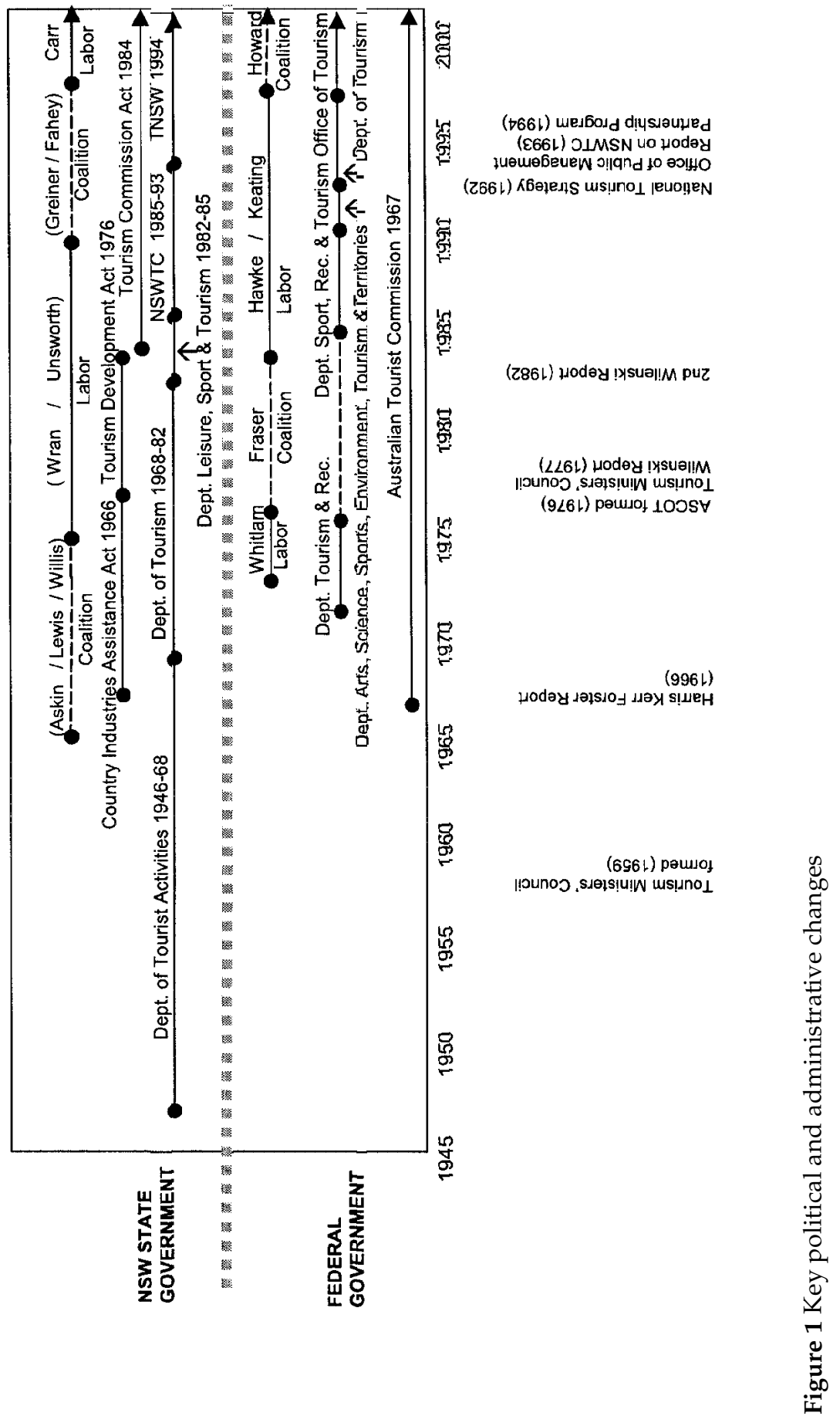


State Government interest in promoting regional development. In a climate where the war had depleted both Commonwealth and State Treasuries, resources and new investment were needed to replace or improve degraded or obsolescent public infrastructure, and tourism was seen as a tool for economic development and a potentially important source of foreign income (Carroll, 1991; Hall, 1998). Moreover, because many attractions were located in regional areas, tourism was also seen as a possible means of promoting population growth outside the capital cities. In the aftermath of the war, there were heightened fears that Australia's concentrated settlement pattern left the country vulnerable to invasion (Commonwealth Department of Post-War Reconstruction, 1949). Populating regional areas was considered a priority and the promotion of tourism was a possible policy solution.

At a Commonwealth-State Tourist Officers' Conference in March, 1946, it was resolved that all Federal and State Departments should cooperate to promote tourism development (Richardson, 1999: 275). In 1947, the NSW State Government responded with the creation of the NSW Department of Tourist Activities and Immigration. One of the Department's roles was to raise the profile of tourism through the declaration of tourism areas and the establishment of tourist offices therein (New South Wales Parliamentary Debates, 1947: 2055). However, declaration of tourism areas depended upon sufficient local interest and the capacity of the community, industry or council to seek such a status. The State did not spell out clear and immediate advantages for becoming a 'declared tourist area', nor did it actively promote such opportunities (New South Wales Parliamentary Debates, 1947: 2055). While State opposition members criticised the patchy and uncoordinated local response, the outcome is perhaps more accurately viewed as a response to two main factors.

First, federal moves to coordinate tourism were viewed as yet another incursion into State sovereignty (Carroll, 1991). In the wake of a High Court decision that income tax collection powers were not to be returned to the States, considerable antagonism between the States and the Federal Government existed and coordination was less than forthcoming. The States' lack of interest in implementing federal policy eventually stifled the Commonwealth's initiatives. In other words, inaction by the States in the local policy arena effectively countervailed federal policy, neutralising attempts to develop national leadership. Secondly, in this early period to 1960 , it was common for tourism infrastructure and plant to be operating at capacity. Calls were made for public investment to modernise tourism infrastructure (New South Wales Parliamentary Debates, 1947: 2054-5). The Labor Government of the time had strong social values (Halligan \& Power, 1992) and placed greater priority on opening up land and providing urban infrastructure to accommodate the growing population. Tourism was not a priority.

By the late 1950s, there was widespread recognition in Commonwealth of Australia parliamentary debates of the importance of tourism as a tool for economic development, and that a coordinated response was required from State and Federal Governments (e.g. see the various speeches under Tourist Trade in Commonwealth of Australia Parliamentary Debates, 1957-60). This rising political interest culminated in the establishment of a Tourism Ministers' Council (TMC) in late 1959. This Council included tourism ministers of all 
States/Territories and the Commonwealth Government. Meeting on an annual basis, it is essentially a formal structure for tourism intergovernmental relations and not a working party.

\section{0-1976}

Expansion of air services, and the staging of the Olympic Games (Melbourne, 1956) and the Commonwealth Games (Perth, 1962), illustrated the growing economic importance of tourism (see the various speeches under 'Tourist Trade' in Commonwealth of Australia Parliamentary Debates 1957-62; also see Hall, 1998; Richardson, 1999). All States were involved in international marketing to some extent, and duplication of marketing was considered costly and inefficient. Once again, the Federal Government identified a need to coordinate State efforts and to develop a national approach to marketing. Harris Kerr Forster was commissioned by the Commonwealth to undertake the first national study of tourism (Carroll, 1991). Among its contributions, this study reinforced awareness of the economic potential of tourism and laid the foundations for the establishment of the Australian Tourist Commission (ATC) in 1967 (see Carroll, 1991; Craik, 1992; Hall, 1998).

Harris et al.'s (1965) report argued that 'The Commonwealth Government should establish an organisation ... for the purpose of coordinating the planning and development of the Travel and Tourist Industry in Australia and the promotion of travel overseas' (p. 76). Several politicians from the government and the opposition parties were critical at the lack of powers and responsibilities of the proposed commission, among other things, pointing to the absence of a coordinating role between the federal and State interests as a serious weakness of the proposed ATC (for a detailed discussion, see Leiper, 1980).

The election of a Coalition (Liberal/Country Party) Government in NSW in 1965 delivered State government support for the development of tourism. The Country Industries Assistance Act 1966 contained NSW's first formal recognition that tourism was an important tool for regional development. The Government strongly supported decentralisation during the late 1960s and early 1970s, with legislation that attempted to stimulate economic development in areas of the State outside the major metropolitan (urban) areas of Sydney, Woolongong and Newcastle. However, the opposition criticised the associated programmes, claiming that the complex administration of funds and dispersed authority (the Department of Decentralisation had ultimate control over expenditure, not the Department of Tourism) reduced policy effectiveness (New South Wales Parliamentary Debates, 1976:933-4). It was to be more than 10 years before this problem was addressed.

While the NSW Government struggled with how best to use tourism as a tool for economic development in regional areas, in 1972 the newly elected federal Labor Government, led by Gough Whitlam, began to expand many areas of public policy, including tourism. Whitlam's Government established the Department of Tourism and Recreation to 'ensure effective co-operation of the planning, development, administration and promotion of travel activity on an Australia-wide basis' (Australian Government Committee of Inquiry Into Tourism, 1986: 48). However, a few years later the Coombs Report on Government Administration recommended 
that the ATC be abolished as a costly saving measure. Alan Greenway (in Richardson, 1999: 289), then Chairman of the ATC, claimed:

It was touch and go whether or not the Commission would survive. As far as the bureaucrats were concerned it was gone. I went to the Prime Minister [Gough Whitlam] and put the case for the ATC as strongly as I could. He listened sympathetically and in the end he prevailed over the bureaucrats.

Labor also greatly increased specific purpose grants for projects the Commonwealth Government considered to be important, but did so without conferring with the States (Aitkin \& Jinks, 1980). In the case of tourism, the Commonwealth attempted to introduce a national licensing scheme to regulate the activities of travel agents and it became more active in domestic marketing activities (Carroll, 1991; Leiper, 1980). Programmes to stimulate the development of tourism infrastructure and expand the Commonwealth Bank's charter to allow it to make loans at marginally favourable interest rates for new tourism projects were also introduced (Carroll, 1991; Commonwealth Government of Australia, 1974). The Commonwealth Department of Tourism and Recreation undertook detailed investigations into such matters as Townsville Airport, tourism in the Ayers Rock-Mt Olga National Park, the Great Barrier Reef, and seasonal holiday demand, and became increasingly involved in domestic marketing (Leiper, 1980). This centralist, interventionist approach heightened CommonwealthState tensions. Duplication of effort and expenditure emerged (Australian Government Committee of Inquiry Into Tourism, 1986). In brief, the Whitlam Government 'earned particular attention from scholars and polemicists, largely because of the quite fundamental questions about policy development, inter-governmental relations and constitutional difficulties for a reform government which enveloped its work' (Wettenhall, 1986: 163). Whitlam was determined to reorganise the departmental structure in order to focus the Commonwealth Government's administrative effort on some of Labor's policy fields for which innovative reforms were planned. Tourism was one such field.

\section{6-1983}

In 1975, Whitlam's term came to a controversial end and the Fraser Government came to power in a period of great public-sector turbulence (see Halligan \& Power, 1992). The 1970s had brought dramatic shifts in processes of government administration in Australia. In 1973, global economic crises followed closely on the heels of massive increases in world oil prices. Governments in developed countries such as Australia, found themselves exposed to strong, and unpredictable global forces largely beyond their control (e.g. Alaba, 1994). As if the problem of economic crises were not enough, several other forces complicated government responses.

In Australia, the 1970s marked the end of a decade of dramatic shifts in lifestyles and values (Alaba, 1994). Compounding 'the effect of the economic crisis and the new demands and complexities of modern government were the examples set by overseas countries which had reviewed their administrations during the previous two decades' (Alaba, 1994: 51). Overseas administrative reform inquiries dating from the 1950s, 'drew attention to the reform inquiry as an instrument for improving Australian systems of government administration 
within international and national environments where resources were becoming less available to support the bureaucratic [s]tate' (Alaba, 1994: 52).

Although 'signs of over-reliance and over-dependence on bureaucratism appeared perhaps for the first time in Australia in the 1890s' (Caiden, 1980: 443), it was a delayed storm that struck Australia with force in the 1970s, as Australians recognised the 'soporific effect of bureaucratism' (Caiden, 1980: 442).

People argued over who was to blame and disagreed over what had to be done next. But they did agree that the public bureaucracy had grown too fat during the good years, that its managerial elite had lost touch with reality, and that public sector performance was just not good enough and had to be improved (Caiden, 1980: 443) (see also Emy \& Hughes, 1988; Halligan \& Power, 1992).

Several Australian Governments commissioned inquiries to advise them on such matters (Caiden, 1980). These led to massive changes in the machinery of government, in the structure of individual federal and State bureaucracies, and in well-entrenched systems of appointment and promotion (for more detailed discussions see Alaba, 1994; Halligan \& Power, 1992; Wilenski, 1977,1982, 1986).

On taking office in 1976, the Fraser Government established a four-member Administrative Review Committee. This committee was required to review government expenditure and provide recommendations on how to eliminate waste and duplications within and between government departments, and between Commonwealth and State departments. Fraser's new federalism policy was echoed in unpublished committee reports, and was accompanied by a commitment to cut government costs. This led to a reshuffling of federal departments and a tidying up of the administration in accordance with notions of functional affinity. Furthermore, in line with tendencies of federal Liberal/Coalition governments to favour a non-interventionist role in tourism (Carroll, 1991), in 1976 the new Fraser Government began to scale back its tourism function. The Commonwealth Department of Tourism and Recreation was abolished and a new Tourist Industry Branch was housed within the Department of Industry and Commerce. Foreign investment continued to flow into Australia as a result of the Commonwealth's taxation policies and industry incentive schemes aimed at stimulating manufacturing, and there was little interest in pursuing other foreign income producing streams (Carroll, 1991). The Fraser Government cut funding for tourism marketing and ordered the ATC (whose budget was cut to $\$ 2.9$ million) to withdraw from domestic marketing. Widespread outcry from the industry led to the revival of the peak association (renamed the Australian Tourism Industry Association (ATIA)) and an investigation by the Industries Assistance Commission (IAC) was undertaken in 1976 (Carroll, 1991). In effect, the above changes shifted a great deal of responsibility for tourism back to the States.

In 1976, the Australian Standing Committee on Tourism (ASCOT) was formed. ASCOT is responsible to the Tourism Ministers' Council (TMC) and comprises representatives from the Commonwealth, State and Territory tourism agencies. ASCOT's functions include improving cooperation and coordination in the formulation and implementation of tourism policy, providing advice and recommendations to the $\mathrm{TMC}$, and attempting to resolve contentious issues 
which may otherwise require the attention of the TMC (Australian Government Committee of Inquiry into Tourism, 1986: 38). The work of ASCOT was instrumental in an agreement reached at a meeting of the Tourism Ministers' Council in October 1976. That agreement formally set out a division of responsibilities between States, Territories and Federal Governments with respect to tourism (Australian Government Committee of Inquiry into Tourism, 1986) (see Table 2), and reflected structuralist views of public administration that dominated the 1960s and 1970s.

The agreement reached was that the Federal Government should have responsibility for international aspects of tourism including international marketing, immigration, foreign investment and international and interstate transportation (Commonwealth Parliamentary Papers, 1988). The States and Territories had primary responsibility for the development of infrastructure and domestic marketing. Given the precarious position of local government in Australia's federal system, where in 1976 it was not recognised constitutionally, the potential roles and responsibilities of local government were not considered in detail. This was left to the States to determine since the powers and responsibilities of local government are determined by State legislation. Historically, the States have fiercely defended their responsibilities against federal incursion and have resented Commonwealth policy initiatives directed at local government. Any effort to examine more closely local government responsibilities in this agreement would have almost certainly met with State resistance.

In 1976, the Wran Labor Government came to power in New South Wales. At the time, there was increasing concern over the effects of the fixed and artificially high value of the Australian dollar upon the balance of tourism receipts. The inflationary spiral of the mid 1970s contributed to a problem where package holidays to overseas destinations were, in many cases, cheaper than domestic holidays (New South Wales Parliamentary Debates, 1976:1060). Outbound tourism was growing strongly and inbound tourism was falling in real terms. The widening gap between inbound and outbound tourism became a real concern prompting the State Government to acknowledge that 'encouraging Australians to holiday at home was an important and pressing challenge' (New South Wales Parliamentary Debates, 1976: 1060-1). However, the NSW Government had little power to address these economic conditions on its own, and called upon the Commonwealth to take a more active stance. Foreign investment continued to flow into Australia as a result of the Commonwealth's taxation policies and industry incentive schemes, and there was little federal interest in addressing these concerns (Carroll, 1991).

The Wran Labor Government did, however, take an active policy stance in other areas where they had greater control in an effort to stimulate tourism product development. The Tourism Industry Development Act 1976 was introduced 'to provide for the development and promotion of the tourist industry throughout the State and to give the Minister for Tourism administrative control over funds expended in his area of responsibility' (New South Wales Parliamentary Debates, 1976: 933).

In 1979, three years after the Fraser Government had withdrawn from active and direct promotion of tourism, and coinciding with a period in which the State 
Table 2 Division of responsibilities as decided by the Tourism Minister's Council, 1976

\begin{tabular}{|c|c|c|}
\hline $\begin{array}{l}\text { Commonwealth } \\
\text { responsibility }\end{array}$ & $\begin{array}{l}\text { Commonwealth/ } \\
\text { State responsibility }\end{array}$ & $\begin{array}{l}\text { tate } \\
\text { sponsibility }\end{array}$ \\
\hline $\begin{array}{l}\text { International relations } \\
\text { (tourism organisation } \\
\text { representation, } \\
\text { international agreements) } \\
\text { Transport - planning, } \\
\text { construction and } \\
\text { maintenance (air, railways, } \\
\text { sea, national highways, } \\
\text { coach interstate operations) } \\
\text { Visitor entry/ exit } \\
\text { formalities (health } \\
\text { regulations, visas and } \\
\text { passports, customs and } \\
\text { excise) } \\
\text { Research and statistics } \\
\text { Environment and } \\
\text { attractions } \\
\text { (Commonwealth } \\
\text { Territories and National } \\
\text { Parks) } \\
\text { National economic policies } \\
\text { (macro economic policy, } \\
\text { foreign investment and } \\
\text { ownership, taxation, } \\
\text { industry assistance, } \\
\text { financial assistance, } \\
\text { international trade and } \\
\text { commerce, etc.) } \\
\text { Promotion and marketing } \\
\text { (marketing of Australia } \\
\text { overseas, development of a } \\
\text { national strategy to } \\
\text { encouragement of } \\
\text { visitation from other } \\
\text { countries) } \\
\text { Consumer affairs (trade } \\
\text { practices) }\end{array}$ & 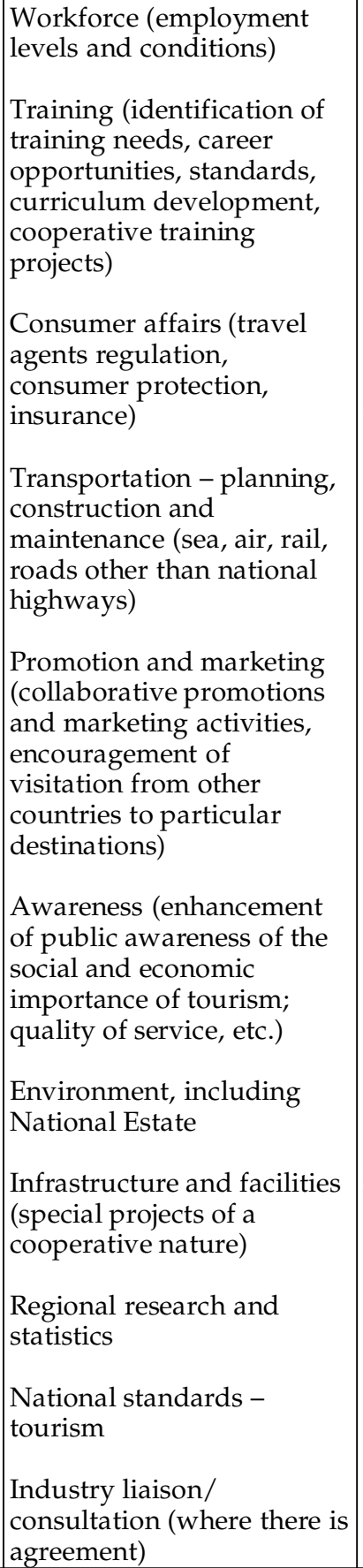 & $\begin{array}{l}\text { Infrastructure and facilities } \\
\text { (sewerage, water, health } \\
\text { services, tourist attractions, } \\
\text { sign posting, picnic and } \\
\text { rest areas, water activities, } \\
\text { parking areas, beach } \\
\text { services, local parks and } \\
\text { lookouts, accommodation, } \\
\text { roads) } \\
\text { Research and statistics } \\
\text { (intra-state collection, } \\
\text { intra-state movement, local } \\
\text { visitation) } \\
\text { Local planning and zoning } \\
\text { industry education } \\
\text { Road transport regulation } \\
\text { Land use and } \\
\text { environmental protection } \\
\text { National parks } \\
\text { Domestic promotion and } \\
\text { marketing } \\
\text { Development finance } \\
\text { (assistance, subsidies, } \\
\text { taxation and other } \\
\text { concessions) } \\
\text { Regulatory services } \\
\text { (building standards, etc.) } \\
\text { Licensing (liquor and } \\
\text { gaming, fishing and } \\
\text { hunting) } \\
\text { Consumer affairs }\end{array}$ \\
\hline
\end{tabular}

Source: Commonwealth Department of Tourism, 1992 
Wran Government had been actively trying to promote investment in tourism infrastructure and marketing, the Fraser Government reassessed its position. A significant policy shift occurred. There had been tensions within the government and opposition parties about the substantial cuts to tourism and to the ATC. Tourism was recognised as an important industry employing 5\% of the work force (see various entries in Commonwealth of Australia Parliamentary Debates, 1979-1980). Following the report of the House of Representatives' Committee on Tourism and a report on the economic significance of tourism by the Bureau of Industry Economics, the Fraser Government increased the ATC's budget to $\$ 8.2$ million, introduced tax concessions for buildings used as tourist accommodation, and money for tourism promotion was incorporated into the Export Markets Development Grant Scheme. The Government also provided fees for WTO membership, and provided several million dollars for the development of attractions and facilities at destinations such as Port Arthur, Ayers Rock and Kakadu (Richardson, 1999: 289).

In retrospect, the period 1976-1983 was characterised by critical changes in the way that both State and Federal Governments dealt with tourism. At a time when tourism was growing rapidly, there was both a growing awareness of the national economic importance of tourism and experimentation with different policy approaches. The lack of historical data to assist decision making, and the absence of specialist education in tourism, and hence tourism 'experts', almost certainly contributed to the trial and error approach. In addition, there has never been a consistent and relatively stable tourism bureaucratic framework or structure in the public service, and so there was little potential to evolve or develop corporate (public sector) knowledge with respect to tourism. Despite the existence of a formal mechanism for intergovernmental cooperation on tourism matters, during this period there was little constructive dialogue between State and Federal Government and agencies about the nature of tourism policy problems, and hence coordinated, and cooperative solutions were not forthcoming. Moreover, the agreement on the division of responsibilities reached by ASCOT reinforced the somewhat limited view that policy problems could be neatly divided, and promoted the traditional status quo between State and Federal Governments where each was perceived to have discrete sovereignties over various aspects of tourism development, marketing and promotion.

\section{4-1989}

By the early 1980s, the parsimonious attitude of the NSW Department of Tourism towards investment in tourism infrastructure and attractions was increasingly criticised. The opposition claimed that NSW had 'failed to grasp the initiative in this potentially important area' (New South Wales Parliamentary Debates, 1985: 8369-70). The NSW Parliament looked north, examining the initiatives taken by the Queensland Government in supporting tourism and in developing closer ties with industry (New South Wales Parliamentary Debates, 1976: 8370). In 1979, the Queensland Government had created a statutory corporation, the Queensland Tourist and Travel Corporation, to more effectively address tourism and develop a closer nexus with industry. It was not long before the NSW Government followed suit.

Shortly after the large-scale reviews of NSW Government administration in 
the 1970s, the Wran Government amalgamated the Department of Tourism and the Department of Sport and Recreation to form the Department of Leisure, Sport and Tourism. The purpose of this amalgamation was to provide for 'more effective and efficient coordination and management' (New South Wales Parliamentary Papers, 1985:1). Following this, the Labor Government repealed the Tourist Industry Development Act 1976 and passed the Tourism Commission Act 1984. Subsequently, the Tourism Commission of New South Wales (TCNSW) was established in February 1985 as a commercially oriented organisation responsible for the coordination of the tourism industry in NSW (New South Wales Parliamentary Papers, 1985: 2). TCNSW took a more active and centralised role in domestic marketing, planning and infrastructure development than it had ever been taken before. Following the example set by Queensland, the Tourism Commission Act 1984, encouraged links with the private sector in an effort to be more responsive to market demand and the needs of private investors.

In 1983, the Fraser Liberal Government was replaced by a Labor Government, marking a rekindling of explicit political interest in tourism. The Commonwealth Department of Sport, Recreation and Tourism was created in 1983 under the leadership of John Brown (Carroll, 1991). This was the second time that tourism had been elevated to a portfolio title, with the previous time being in 1974 as part of the Department of Tourism and Recreation, and coinciding again with a Labor Government.

In 1986, the Australian Government Inquiry into Tourism was initiated. The inquiry's Terms of Reference required it to 'examine, report and make recommendations to the Minister for Sport, Recreation and Tourism on the effectiveness of Commonwealth administration of its tourism promotion functions and related issues' (p. 5). Among other things, the inquiry was required to review 'relationships between the Australian Tourist Commission and Commonwealth, State and other organisations with responsibilities that impact on tourism' (p. 5). Among its findings were several recommendations calling for greater coordination within the Commonwealth Government, and between government and agencies at different levels of government. Indeed, 'the predominant theme emerging from the Inquiry was the need for a co-ordinated tourism framework which would encourage an integration of the efforts of a wide range of tourism related interests' (Australian Government Committee of Inquiry into Tourism, 1986:57). Interestingly, no critical analysis was undertaken of the complexities of coordinating public policy and developing intra- and inter-governmental relations in a federal system per se. The only detailed comment that specifically mentioned federalism and the Australian Constitution came from a submission by Qantas Airways:

Integration is probably the most important insofar as tourism has yet to bring all of its divergent parts into one cohesive whole... Our country's constitutional framework, with numerous independent states, has had negative consequences in tourism development. In pursuing their own independent policies and aspirations, the individual states have in certain circumstances tried to promote one at the expense of the others and inadvertently at the expense of Australia overall. 


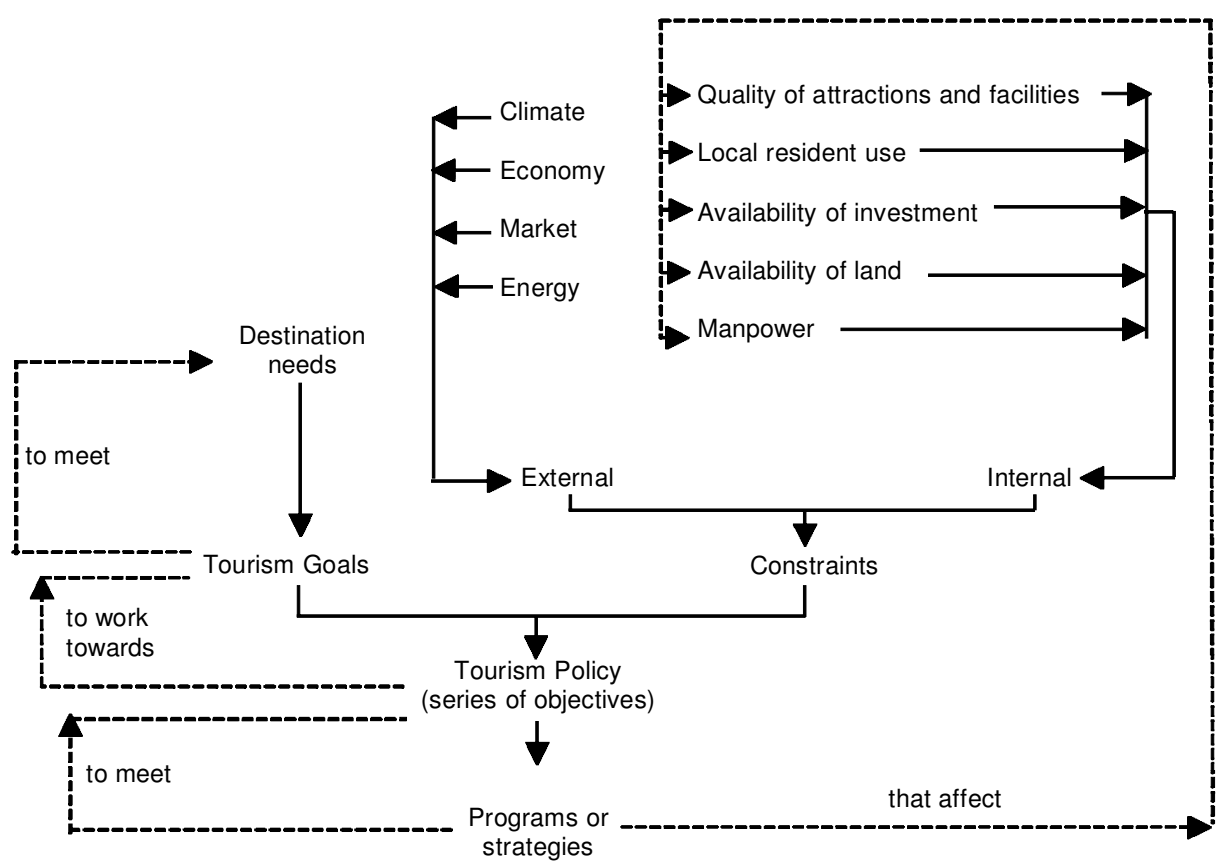

Figure 2 Mill and Morrison's (1985) Tourism Policy Model from the 1986 Inquiry into Tourism

Source: Mill and Morrison, 1985, in Australian Government Committee of Inquiry Into Tourism, 1986:39

Policy models and government roles were proposed, and most were based on Mill and Morrison (1985: 17-21, 39). Figure 2 shows the Tourism Policy Model put forward as an outcome of the inquiry. This model largely ignored more advanced public policy discussions by political scientists and public policy analysts in Australia and overseas. The tourism policy model had little, if any, relevance to Australia's institutional frameworks and associated public policy processes, much less the complex institutional arrangements in the federal system. It is worth noting, too, that the report argued that:

existing formal mechanisms for policy co-ordination (including the Tourist Ministers' Council, the Australian Standing Committee on Tourism and the Tourism Advisory Committee) have been criticised as ineffective and lacking a solid base. The existing Tourist Ministers' Council Agreement contains too many grey areas and there is no formal mechanism for review of action taken against responsibilities (p. 59).

Prior to 1990, Federal policy of the Labor Government sought to stimulate tourism on two levels. First, programmes were put in place that actively promoted tourism planning and infrastructure development (Econsult Management Consultants, 1989). Secondly, policies were aimed at breaking down trade barriers and easing regulatory requirements that, in turn, were to stimulate growth and investment in tourism. These included a decision to deregulate the 
aviation industry and relaxation of rules concerning foreign investment. It was these rules that opened up opportunities for State Governments to pursue more freely overseas investment in Australia's tourism infrastructure and assisted the tourism development boom of the late 1980s.

In addition, the Steel Industries Assistance Program, which sought to address the economic problems associated with a decline in mining and heavy manufacturing industries, was used to channel large amounts of federal money into specific regions. Over the five years to 1988 , more than $\$ 10$ million was allocated to the development and promotion of tourism in the Hunter and Illawarra regions (Commonweal th of Australia Parliamentary Papers, 1988). While these funds were channelled through the State, and specifically the NSW Tourism Commission in an effort to minimise State-federal tensions, this programme ensured that some regional organisations became quite powerful relative to others. It could even be argued that the Commonwealth, in attempting to address perceived inequalities in regional economic development, only assisted in reinforcing an uneven playing ground, and it did so with minimal consultation with the State. Given the fiscal imbalance, any funding offered by the Federal Government, however, would have almost certainly ensured State cooperation.

In sum, the period 1984 to 1989 brought renewed political interest in tourism at federal and State levels. The complexity of overlapping responsibilities and the lack of coordination was highlighted as a serious constraint, but the solutions put forward in the findings of the federal inquiry lacked practical application in the face of political and administrative realities. Both Federal and NSW State Governments continued to deal with tourism policy independently and within their broadly defined powers and responsibilities. While Federal and State Governments recognised the need for coordination, the status quo of coexisting policy development continued.

\section{0-1993}

By the late 1980s, tourism was poised to become Australia's largest foreignincome generator and had become one of the federal Labor Government's policy priorities (Commonwealth Department of Tourism, 1992). The Federal Government directed the Industries Assistance Commission (IAC) to hold an inquiry into the travel and tourism industries and report on factors affecting the development of tourism, including major impediments to competitiveness and efficiency (Industries Assistance Commission, 1989). The commission found that impediments to the development of the industry lay predominantly in the transport services sector, although other factors such as employment, training and safeguarding community interests were also identified. These impediments no doubt reflected the Commonwealth's range of concerns, although limited attention was also given to areas where the States, and local government, play a major role. For example, the lack of local infrastructure, resource management and strategic planning were identified as concerns, but few recommendations were made in this regard. While measures directly relating to the Commonwealth's responsibilities such as the deregulation of transport sectors were later introduced, the report also recommended that an integrated and holistic policy approach was required. It was this recommendation that laid the groundwork for Commonwealth attempts to develop leadership in the tourism policy arena. 
The Commonwealth Department of Tourism (CDoT) was created at the end of 1991, and by June of the following year, Australia's first national tourism strategy, Tourism: Passport to Growth, had been released (Carroll, 1991). The release of the strategy illustrated the Labor Federal Government's strong commitment to coordinate tourism and the Commonwealth's need to exercise hegemony. Yet the Federal Government was also conscious of the complex and overlapping division of governmental responsibilities, and, in framing the strategy, aimed at 'striking a balance between being broad enough to cover all areas of interest and targeted enough to provide clear direction on key issues' (Commonwealth Department of Tourism, 1992).

The National Tourism Strategy was implemented through six programmes, the Regional Tourism Development Program, the National Ecotourism Program, the Sites of National Tourism Significance Program, the Forest Ecotourism Program and the Rural Tourism Program. State, regional and local agencies and organisations were eligible to apply for funding to undertake wide-ranging projects including, for example, infrastructure development, local and regional planning, site management, and to develop marketing strategies. Some States and Territories perceived that these projects were an incursion into their areas of responsibility, a feeling that was heightened when funding went directly to local government or to regional organisations. The States considered themselves to be in a better position to identify local and regional needs, being the 'creators' of such organisations. However, there was little or no formal consultation, and the distribution of funds may have reflected Commonwealth electoral interests rather than genuine regional and local needs (Jenkins \& Sorensen, 1996).

Over the same period there were also significant changes in the NSW policy approach. A Liberal Government led by Nick Greiner came to power in 1989, with an approach to administrative change that could only be described as 'comprehensive, systematic and speedy' (Halligan \& Power, 1992: 119). Embracing neo-liberal economic philosophies, the Government placed emphasis on efficiency and competitiveness in the global marketplace. In a managerialist approach to reform of the public sector, the Greiner Government focused 'intently on results and resource use, revolutionised the role of statutory authorities, recast the senior public service, and maintained centrality of managerialism' (Halligan \& Power, 1992: 119). Significant reforms were introduced in many areas of policy, including tourism. The NSW State Government heavily promoted regional tourism planning and management, embracing a centralised leadership role in the preparation of a State-wide plan for tourism. Under new funding arrangements, local government was encouraged to prepare local tourism strategies, but the lack of political commitment to planning for tourism among cash-strapped councils meant that many of these documents were produced solely for the purpose of accessing additional funds (Dredge, 2001).

The period 1990 to 1993 was characterised by proactive policy development at both federal and State levels. The Federal Government sought to develop national hegemony via the release of the National Tourism Strategy. The strategy fell well short of its underlying objective of substantive national leadership, though a couple of initiatives that stemmed from the National Strategy (e.g. the Ecotourism Strategy) have led to important short and medium term programmes and outcomes (e.g. see Weaver, 2001). Nevertheless, expansion of 
federal policy interest meant that relations between governments were, at times, strained. The NSW State Government, in developing its regional planning framework and coercing local government participation using funding incentives, also tried to develop centralised leadership in product development and marketing. Promoting tourism internationally, and improving the State's competitive edge on the world stage, were tasks over which considerable overlap of policy efforts and expenditure emerged. A review of the TCNSW conducted by the NSW Office of Public Management (OPM) in 1993, however, brought fundamental changes to the State's tourism policy direction and laid the ground for another significant policy shift.

\section{4-2000}

Among the many changes that took place in New South Wales as a result of the OPM report, the TCNSW was renamed Tourism New South Wales (TNSW) and emphasis was given to increasing economic efficiency and developing a stronger corporate strategic focus that would provide leadership and a vision for tourism development across the State. In 1995, the Labor party, led by Bob Carr, replaced the Liberal Government, and embraced the policy approach developed by its predecessors. A number of State-wide strategic planning exercises were undertaken, including the NSW Tourism Master Plan to 2010 and associated action plans (1995 and 1998), regional tourism strategies $(1997,2001)$ and the Regional Attractions Strategy (1999). At the same time, TNSW withdrew its focus on regional planning and coordination, and through the presence of a TNSW officer in each region, has tried to foster skill development, resource building and knowledge within each region so that an organic, regional form of leadership could emerge. Assistance in developing RTO (Regional Tourism Organisation) leadership in regional marketing and product development activities was boosted and support for other stakeholders, including local government, was reduced. At the same time, local government is considered to be an important partner in regional tourism (TNSW, 1999), and dollar for dollar funding in marketing programmes offered by TNSW, and channelled through the RTOs, coerce many councils into continued cooperation (Dredge, 2001).

In 1994, as the OPM report was being prepared, the Commonwealth Government began taking an active interest in improving the coordination of overseas marketing and promotional efforts (Hall, 1998). In particular, the Partnership Australia scheme sought agreement between the ATC and the various State and Territory tourism agencies to develop a coordinated approach to information and booking facilities for all Australian travel products. While an intergovernmental agreement setting out the responsibilities and roles of the States/Territories and the Federal Government had been in place since 1976, and had been ratified on a number of occasions, it had done little to stem the overlap in federal-State policy initiatives. The Partnership Australia scheme was the first real initiative that sought to address functional overlaps in marketing and promotion at an operational level. Partners include the ATC, State and Territory marketing organisations/authorities, and private industry. Partnership Australia was devised to overcome coordination problems with the way the Australian tourism product is developed and marketed overseas. The principal objectives of Partnership Australia have been to: 
coordinate Australia's international tourism marketing and promotional efforts to improve efficiency and effectiveness (thereby eliminating costly duplication and fragmentation in marketing);

develop a wider range of tourism products for international markets;

provide information to overseas consumers and industry to generate more sales and extend product distribution; and

motivate and train the overseas trade to sell Australia better (Australian Tourism Commission, 1993, 1995.

There have been some problems with members disagreeing about the constitution of the ATC board, the direction of marketing activities and proportional representation of States in such programmes (for a more detailed discussion see Jenkins, 2001). While all States/Territories have continued to participate, the scheme does not appear to have stemmed duplication of effort and expenditure in some areas, such as international marketing. The particular product strengths and differences in markets characteristics have tended to promote competition between States/Territories as they strive to promote their own products and images to the world in order to boost their own share of the international market.

In 1996, the Howard-led Liberal Government came to power, and the national tourism strategy was withdrawn. In its place, the Federal Government released a national action plan that sought 'to provide a national framework for tourism policy formulation and industry planning' (Commonwealth Department of Industry, Science and Tourism (CDIST), 1998: 2). Entitled Tourism: A Ticket to the 21st Century, the plan moved away from the direct initiatives of the previous Government, opting for a much broader role in creating the right economic, regulatory and business environment. It was considered that many issues relating to tourism could be satisfactorily addressed under other federal policy statements and programmes (Commonwealth Department of Industry, Science and Tourism, 1998). In particular, programmes associated with stimulating business innovation, investment and exports were considered appropriate mechanisms to assist tourism growth and development, as were the Centenary of Federation Funds and the Natural Heritage Trust. The Regional Tourism Development Program was renamed the Regional Development Program and all other programmes were abolished. The Government set aside $\$ 8$ million over four years to $2000 / 1$ to enhance the tourism potential of regional and rural Australia under this programme.

Interestingly, while the action plan supported the development of constructive partnerships, and acknowledged that success depended upon the cooperation of all stakeholders, 'it focus[ed] on national issues and [was] not intended to impinge on the specific responsibilities of State, Territory or local governments' (Commonwealth Department of Industry, Science and Tourism, 1998: 2). This appears to have been an attempt by the Coalition Government to distance itself from the position taken in the previous national tourism strategy that sought to develop a hegemonic role in tourism.

The period 1994-2000, therefore, was one in which the traditional status quo between the State and Federal Government re-emerged. The Federal Government has withdrawn from an active, hegemonic stance in developing a national tourism policy, which was a familiar feature of the Hawke and Keating Labor 
Governments. Nonetheless, the Howard Federal Government is intent on supporting the tourism industry, and has not scaled back the now familiar and large injections of funds for international tourism marketing and promotion, and for the development of infrastructure and facilities.

\section{Discussion}

This paper has illustrated that growth in tourism activity and its expanded economic importance has opened up a quagmire of overlapping policy roles and responsibilities between the State and Federal Governments. Although this lack of coordination has long been recognised as a significant impediment to the development of effective tourism policy, State and Federal Governments have continued to engage in policy development with minimal collaboration. The negative effects of countervailing power and multiple accountabilities, identified in Figure 1, are clearly discernable. From this case study, three overlapping and deeply interrelated aspects that have had a significant impact upon intergovernmental relations in the tourism sector can be identified: globalisation, the organisation of tourism and public policy making. These aspects have problematicised the notion of dividing responsibilities between semi-sovereign governments. The Intergovernmental Agreement on Tourism (1976) and its rigid division of responsibilities had a limited 'shelf-life'. While the agreement was a product of the reigning structural-functionalist philosophies about public administration and intergovernmental relations of the time, these philosophies were based on the notion that unity and order could exist and a particular government's range of concerns was finite, determined by authoritative constitutional interpretation. However, over the course of the last 25 years, the increasing complexity and overlapping of tourism policy making between State and Federal Governments suggests that the structuralist approach does not reflect the dynamic realities of a globalising world. In the following discussion we argue that there are powerful connections between globalisation, the organisation of tourism and tourism public policy making. Explicit examination of these relationships can provide important insights into the growing complexity of overlapping policy making environment and understandings of government interests and interrelations. Only through these understandings can cooperative intergovernmental relations be improved.

There has been considerable attention given to the broad processes of globalisation and its impacts upon policy making in recent years (see Introduction). Among the many effects of globalisation upon tourism there has been an opening up of new and diverse markets, rapid innovation in tourism products, increased competition between destinations, and a stronger focus on regional product clustering and brand marketing. These effects, along with growing recognition that tourism can be an important source of foreign income and regional economic development, have stimulated governments' interests in identifying and addressing tourism policy issues. However, the way that NSW State and Federal Governments have identified policy problems, in terms of State and federal interests respectively, have differed. For example, Federal Government, through the ATC, has developed policy initiatives aimed at the generic marketing of the Australian tourism product to domestic and international 
markets. NSW, like most other States/Territories, has been keen to increase its share of the international market. The NSW approach has been to develop and promote directly to international markets its own NSW brand, comprising a range of regional products. This approach has put the States/Territories in direct competition with each other, as well as in direct competition with the generic marketing fostered by the Federal Government. As a result, tourism marketing is one area where significant duplication of effort has occurred. Collaborative marketing and promotion appears to be contrary to the agendas of both Federal and NSW Governments, even though both Governments have acknowledged significant duplication of effort. Not surprisingly, tourism marketing and promotion has been a difficult area of intergovernmental relations.

Experimentation with different organisational forms (e.g. sector-specific government departments, offices of tourism within mega-departments, statutory corporations, support of ind ustry associations) at both levels of government reflect varied attempts by governments to address increasing competition in the market place and to breakdown barriers to product innovation. There are two important effects of these shifts on the organisation of tourism. First, relationships between government and private sector interests, represented by peak organisations and individuals on statutory corporation boards, for example, have changed in attempts to make government policy more responsive to the needs of the tourism industry and to increase market competitiveness. These changes in the organisational structures of tourism, at both State and federal levels, have been partially explained by the dominant ideologies of governing Liberal or Labor parties (see Carroll, 1991a; Jenkins, 2001). However, organisational change occurring at both State and federal levels can also be understood as the result of the dynamic nature of problem definition. Powerful forces operating across global, national, regional and local scales have contributed to the continual shaping and redefinition of tourism policy problems, which have, in turn, led to instabilities in the organisation of tourism over time.

Secondly, the dynamic and innovative nature of tourism has contributed to its continual reorganisation. Tourism markets are volatile and highly competitive. Product development requires a policy environment that facilitates innovation in order to maintain a competitive edge. As a result, the identification of tourism policy problems, much less identification of solutions, is akin to hitting a moving target. In this view, the organisation of tourism is inherently unstable; roles and responsibilities require continuous definition and redefinition.

State and federal tourism policy making should not however be viewed simply as a response to globalisation or different organisations of tourism. Political ideologies, party politics, significant individuals (e.g. politicians, business leaders), interest groups and institutions influence how globalising pressures are interpreted, given meaning and addressed in public policy debates. Even though globalisation has been a constant force shaping public policy debates since the 1980s, as different political parties have come to power, the identification and prioritisation of policy problems have changed. Even successive governments, although embracing prevailing neo-liberal economic management philosophies, have tended to re-prioritise or dismantle previous governments' policy solutions based on their own interpretations of policy problems. Not surprisingly then, there has been little coordination between Federal and State Governments, 
which have different constitutional and jurisdictional responsibilities, and which are subject to quite independent electoral cycles. Coordination, while most certainly a noble priority under globalisation, is difficult in practice, and has challenged the tourism policy process for many decades.

\section{Conclusions}

In a move away from the traditional emphasis upon the inadequacies and disadvantages of federalism, this paper has sought to develop greater understandings of intergovernmental relations and to assess opportunities for and impediments to cooperative federalism. Clearly, many of the challenges to cooperative federalism are derived from the way that driving forces beyond national borders are interpreted by State and National Governments. Globalising markets, increasing competition, dynamic, innovative product development and the effects of broad economic conditions, impact upon the interpretation of policy problems and the identification of solutions. Traditional competition between the States and Federal Government and concerns about sovereignty have underpinned relations between Federal and State Governments resulting in the absence of any concerted effort to coordinate tourism policy making. Moreover, while the absence of coordination has been recognised as an impediment to the development of an effective tourism policy approach, policy solutions thus far have tended to ignore dynamic political and administrative realities.

Federalism, its system of divided sovereignties and the competition that it instils, magnifies, distorts and confuses roles and responsibilities. Each unit of government is responding to different market and product development pressures. The definition of policy problems in both State and federal arenas is constantly changing, and with this, tourism policy and administration are in a state of flux. Policy making by State and Federal Governments verges on competition, where development of tourism in the national interest has often been seen as contrary to the interests of developing and promoting NSW tourism. Competition between the States, to increase tourism markets and consolidate the State's own competitive advantage, is also strong.

It is surely a feckless exercise, however, to simplistically see these possible developments as disadvantageous to tourism. In short, much more balanced interpretations of tourism policy making in Australia's federal system are needed, and criticisms as to the lack of clarity in divisions of responsibilities need to give way to much more reflective discussions about the impact of globalisation on tourism policy making, policy cycles and policy learning. Heightened sensitivity to the diversity and fluidity of tourism policy, administration and organisations is also required.

Opportunities for cooperative tourism policy making require an emphasis upon communication, information sharing and collaboration at the administrative level. Previously, massive shifts in the organisation of tourism at State and federal levels have destabilised communication channels and information sharing and reduced opportunities for cooperative policy making. Shared understanding of issues from the viewpoints of other units of government can help to build organisational structures and processes that are anchored in 
addressing fundamental issues about how to build a competitive, efficient and innovative tourism industry. While political cycles will inevitably result in changes to policy solutions and priorities, the organisation of tourism around on-going, sustainable networks of relations between State and Federal Governments, rather than formal political structures, might allow tourism to ride waves of political and administrative change.

\section{Correspondence}

Any correspondence should be directed to Dianne Dredge, School of Environmental Planning, Griffith University, Nathan, QLD 4111, Australia (D.Dredge@ griffith.edu.au).

\section{References}

Aitkin, D. and Jinks, B. (1980) Australian Political Institutions. Melbourne: Pitman Australia.

Alaba, R. (1994) Inside Bureaucratic Power: The Wilenski Review of New South Wales Government Administration. Marrickville: Hale and Iremonger.

Australian Bureau of Statistics (ABS) (2000) Taxation Revenue. Canberra: Australian Bureau of Statistics. (Catalogue no. 5506.0)

Australian Government Committee of Inquiry Into Tourism (1986) Report of the Australian Government Inquiry into Tourism. Canberra: AGPS.

Australian Tourism Commission (ATC) (1993) Australia. Sydney: Australian Tourism Commission.

Australian Tourism Commission (ATC) (1995) Partnership Australia: Information for Australian Tourism Operators. Sydney: Australian Tourism Commission.

Balmer, C. (1989) Local government in the federal system. In A.L.G. Association (ed.) The Australian Local Government Handbook (pp. 1-7). Canberra: Australian Government Printing Service.

Bramwell, B. and Lane, B. (eds) (2000) Tourism Collaboration and Partnerships: Politics, Practices and Sustainability. Clevedon: Channel View.

Bramwell, B. and Sharman, A. (1999) Collaboration in local tourism policy-making. Annals of Tourism Research 26 (2), 392-415.

Caiden, G. (1980) Administrative reform. Australian Journal of Public Administration 39 (3/ 4), 437-53.

Carroll, P. (1991) The federal government and tourism 1945-1990. In P. Carroll, K. Donohue, M. McGovern and J. McMillen (eds) Tourism in Australia (pp. 68-81).Sydney: Harcourt Brace Jonanovich.

Chapman, R. (1997) Intergovernmental relations. In B. Dollery and N. Marshall (eds) Australian Local Government: Reform and Renewal (pp. 40-68). Melbourne: Macmillan Education.

Chapman, R. and Wood, M. (1984) Australian Local Government: The Federal Dimension. Sydney: Allen \& Unwin.

Commonwealth Department of Industry Science and Tourism (1998) Tourism: A ticket to the 21st century. A national action plan for a competitive Australia. On WWW. Accessed 8.10.99.

Commonwealth Department of Post-War Reconstruction (1949) Regional Planning in Australia. Canberra: A.H. Pettifer Government Printer.

Commonwealth Department of Tourism (1992) Tourism - Australia's Passport to Growth. Canberra: AGPS.

Commonwealth Government of Australia (1974) Australian Government Assistance to Local Government Projects: Sources of Funding and How to Apply for Them. Canberra: AGPS.

Commonwealth Parliamentary Debates (1957’60). House of Representatives. Canberra: Government Printer. 
Commonwealth Parliamentary Papers (1988) Department of the Arts, Sport, the Environment, Tourism and the Territories Annual Report 1987-88 (vol. 24, no. 251). Canberra: AGPS.

Craik, J. (1992) Australian tourism: The emergence of a state coordinated consultative framework. In S. Bell and J. Wanna Business-Government Relations in Australia (pp. 231-42). Sydney: Harcourt Jonanovich.

Dredge, D. (2001) From workers' paradise to leisure lifestyles: Cultural and structural dynamics of tourism policy networks in Lake Macquarie, New South Wales, Australia. Unpublished PhD thesis, University of Newcastle.

Econsult Management Consultants (1989) Tourism and Local Government in Australia: An Evaluation of Local Government Development Program Support. Canberra: Commonwealth Department of Immigration, Ethnic Affairs and Local Government.

Elliot, J. (1997) Tourism: Politics and the Public Sector. London: Routledge.

Emy, H.V. and Hughes, O.E. (1988) Australian Politics: Realities in Conflict. Melbourne: Macmillan.

Fagan, R.H. and Webber. M. (1994) Global Restructuring: The Australian Experience. Melbourne: Oxford University Press.

Fenna, A. (1998) Introduction to Policy Analysis. Melbourne: Longman.

Galligan, B. (1995) A Federal Republic: Australia's Constitutional System of Government. Cambridge: Cambridge University Press.

Galligan, B., Hughes, O. and Walsh, C. (1991) Intergovernmental Relations in Australia. Sydney: Allen and Unwin.

Hall, C.M. (1998) Introduction to Tourism: Development, Dimensions and Issues (3rd edn). Melbourne: Longman.

Hall, C.M. (1999) Tourism Planning: Destinations, Organisations, People and the Environment. Harlow: Addison Wesley Longman.

Hall, C.M. and Jenkins, J. (1995) Tourism and Public Policy. London: Routledge.

Hall, C.M., Jenkins, J.M. and Kearsley, G. (1997) Tourism Planning and Policy in Australia and New Zealand: Cases, Issues and Practice. Sydney: Irwin.

Halligan, J. and Power, J. (1992) Political Management in the 1990s. Melbourne: Oxford University Press.

Hede, A. and Prasser, S. (1993) Policy-making in Volatile Times. Sydney: Hale and Iremonger.

Henderson, J. (2001) Regionalization and tourism: The Indonesia-Malaysia-Singapore growth triangle. Current Issues in Tourism 4 (2-4), 78-94.

Hollinger, R. (1994) Postmodernism and the Social Sciences: A Thematic Approach. Thousand Oaks: Sage.

Holmes, J. and Sharman, C. (1977) The Australian Federal System. Sydney: Allen and Unwin.

Industries Assistance Commission (IAC) (1989) Travel and Tourism (423). Canberra: AGPS.

Jefferies (2001) Tourism and Government. London: Butterworth Heinemann.

Jenkins, J. (1995) A comparative study of tourist organisations in Australia and Canada. Australian-Canadian Studies 13 (1), 73-107.

Jenkins, J. (2001) Statutory authorities in whose interests? The case of Tourism New South Wales, the Bed Tax and 'The Games'. Pacific Tourism Review 4 (4), 201-18.

Jenkins, J. and Sorensen, T. (1996) Tourism, regional development and the Commonwealth: A critical appraisal of the regional tourism development program. Australian Leisure 7 (4), 28-35.

Leiper, N. (1980) An interdisciplinary study of Australian tourism: Its scope, characteristics and consequences, with particular reference to governmental policies since 1965. Unpublished MA thesis, University of New South Wales, Sydney.

Lovelock, B. (2001) Intergovernmental relations in the protected areas-tourism policy domain: The influence of macro-economic policy. Current Issues in Tourism 4 (2-4), 253-74.

Marshall, N. (1997) Introduction: Themes and issues in Australian local government. In B. 
Dollery and N. Marshall (eds) Australian Local Government: Reform and Renewal (pp. 1-14). Melbourne: Macmillian Education Australia.

Mathews, R.L. (1974) Introduction. In R.L. Mathews (ed.) Intergovernmental Relations in Australia (pp. 1'9). Sydney: Angus and Robertson.

Mercer, D.C. (2000) A Question of Balance. Natural Resources Conflict Issues in Australia. Leichhardt: Federation Press.

Mill, R. and Morrison, A. (1985) The Tourism System: An Introductory Text. Englewood Cliffs: Prentice Hall.

New South Wales Parliamentary Debates (1947) Pp. 2054-5. Sydney: NSW Government Printer.

New South Wales Parliamentary Debates (1976) Pp. 933-8 and 1058-72. Sydney: NSW Government Printer.

New South Wales Parliamentary Debates (1985) Pp. 8369-71. Sydney: NSW Government Printer.

New South Wales Parliamentary Papers (1985) Report of the Tourism Commission of New South Wales for the Period 1 February to 30 June 1985 (395). Sydney: NSW Government Printer.

Painter, M. (1988) Australian federalism and the policy process: Politics with extra vitamins. Politics 23 (2), 57-66.

Painter, M. (1996) The Council of Australian Governments and Intergovernmental Relations: A case study of co-operative federalism. Publius 26 (2), 101-21.

Painter, M. (1998a) Collaborative Federalism: Economic Reform in Australia in the 1990s. Cambridge: Cambridge University Press.

Painter, M. (1998b) Public relations reform, intergovernmental relations and the future of Australian federalism. Australian Journal of Public Administration 57 (3), 52-63.

Parkin, A. (1996) South Australia, Federalism and Public Policy: Essays Exploring the Australian Federal System on Government and Public Policy in South Australia. Canberra: Federalism Research Centre, Australian National University.

Pearce, D. (1992) Tourist Organizations. Essex: Longman Scientific and Technical.

Pearce, D. (1996a)Federalism and the organization of tourism in Belgium. European Urban and Regional Studies 33, 189-204.

Pearce, D. (1996b) Tourist organizations in Calatonia: Regional and local structures and issues. Progress in Tourism and Hospitality Research 2, 307-20.

Pearce, D. (1996c) Tourist organizations in Sweden. Tourism Management 17 (6), 413-24.

Reid, G.S. (1974) Political decentralisation, co-operative federalism and responsible government. In R.L. Matthews (ed.) Intergovernmental relations in Australia (pp. 23-42). Sydney: Angus and Robertson.

Richardson, J.I. (1999) A History of Australian Travel and Tourism. Melbourne: Hospitality Press.

Riker, W.H. (1964) Federalism, Origin, Operation and Significance. Boston: Little Brown.

Saunders, C. (1986) The federal system. In B. Galligan (ed.) Australian State Politics. Melbourne: Longman Cheshire.

Selin, S. and Beason, K. (1991) Interorganizational relations in tourism. Annals of Tourism Research 18 (4), 639-52.

Tourism New South Wales (TNSW) (1999) Attractions Development Strategy for Regional New South Wales. Sydney: Tourism New South Wales.

Wanna, J., O'Faircheallaigh, C. and Weller, P. (1992) Public Sector Management in Australia. Melbourne: Macmillan Education Australia.

Watts, R.L. (1999) Comparing Federal Systems. Montreal: McGill-McQueens University Press.

Weaver, D. (2001) Ecotourism. Milton, Queensland: John Wiley.

Wettenhall, R. (1986) Organising Government: The Uses of Ministries and Departments. Sydney: Croom Helm.

Wilenski, P. (1977) Directions for Change: An Interim Report. Review of New South Wales Government Administration. Sydney: NSW Government Printer.

Wilenski, P. (1982) Further Report: Unfinished Agenda. Second Report on the Review of New South Wales Government Administration. Sydney: NSW Government Printer. 
Wilenski, P. (1986) Competing Values in Public Administration, Public Power and Public Administration (pp. 50-63). Sydney: Hale and Iremonger.

Wiltshire, K. (1986) Intergovernmental Relations and Planning. Brisbane: University of Queensland Press. 